\title{
Infrared skin temperature measurements for monitoring health in pigs: a review
}

\author{
Dennis Dam Soerensen ${ }^{*}$ and Lene Juul Pedersen
}

\begin{abstract}
Infrared temperature measurement equipment (IRTME) is gaining popularity as a diagnostic tool for evaluating human and animal health. It has the prospect of reducing subject stress and disease spread by being implemented as an automatic surveillance system and by a quick assessment of skin temperatures without need for restraint or contact. This review evaluates studies and applications where IRTME has been used on pigs. These include investigations of relationships between skin, ambient and body temperatures and applications for detecting fever, inflammation, lesions, ovulation, and stress as well as for meat quality assessment. The best skin locations for high correlation between skin temperature and rectal temperature are most likely thermal windows such as ear base, eye region and udder. However, this may change with age, stressors, and biological state changes, for example, farrowing. The studies performed on pigs using IRTME have presented somewhat discrepant results, which could be caused by inadequate equipment, varying knowledge about reliable equipment operation, and site-specific factors not included in the assessment. Future focus areas in the field of IRTME are suggested for further development of new application areas and increased diagnostic value in the porcine and animal setting in general.
\end{abstract}

Keywords: Infrared thermography, Temperature, Fever, Thermoregulation, Pig

\section{Introduction}

Infrared thermography (IRT) and infrared thermometry (IRTM) are non-contact temperature measurement methods, which offer several advantages over other temperature measurement methods used in veterinary medicine. Infrared (IR) temperature measurements considerably reduce the risk of spreading infection, since touching the subject is unnecessary. In animals, this is advantageous since handling and restraint increases stress, causing an effect on core and surface temperatures [1-7]. Due to the non-obtrusive nature of IRTME, it is an insignificant stressor, theoretically making it well-suited for assessment of animal stress and welfare. The potential of IRTME is reflected in the various applications for which it has been used. IRT was used successfully for detecting meat defects [8-12] and has been attempted for predicting estrus from vulva surface temperature [13-15]. Others have used IRTM [16] and IRT $[17,18]$ in feed and digestion studies to evaluate its suitability for, aiding or replacing calorimetry. IRTME

\footnotetext{
* Correspondence: DennisD.Sorensen@agrsci.dk

Department of Animal Science, Aarhus University, Blichers Allé 20, PO Box 50, DK-8830 Tjele, Denmark
}

(c) 2015 Soerensen and Pedersen; licensee BioMed Central. This is an Open Access article distributed under the terms of the Creative Commons Attribution License (http://creativecommons.org/licenses/by/4.0), which permits unrestricted use,

distribution, and reproduction in any medium, provided the original work is properly credited. The Creative Commons Public Domain Dedication waiver (http://creativecommons.org/publicdomain/zero/1.0/) applies to the data made available in this article, unless otherwise stated.

does not affect the temperature of the object surface by conduction or convection, which is the case with regular temperature sensors. IRT acquires thermal images, enabling measurement of surface temperature distributions, suited for detecting localized anomalies. It is possible to select regions of interest (ROIs) in the thermal images, thereby only selecting specific areas of interest for subsequent data analyses. These ROIs may be analyzed by spots (e.g. single pixel), lines, or areas of various shapes. While IRT produces thermal images with many pixels, IRTM utilizes only one pixel, which measures the average temperature of the area it covers.

IRT is fitting for measuring skin temperature in pigs, since pelage of pigs is different than many other mammals, which have more hair coverage. Even though pig hair is much coarser than human hair, hair density is comparable to that of humans [19], offering several bare skinned surface areas.

Reviews covering the use of IRTME on animals [20-24] have had very little focus on pigs. The aim of this review is to assemble studies investigating use of IRTME on pigs with focus on the temperature relationships between 
environment, skin, and body as well as detection of fever and other health issues.

\section{Surface temperature in relation to ambient temperature}

Thermoregulatory ability in pigs increases with age. As opposed to a piglet having less than $2 \%$ body fat during the first two weeks of life [25], an adult pig has a thicker fat layer, a denser hair coat and a smaller surface to volume ratio, enabling them to limit the heat flow from the body core to the surroundings. From here on, body core temperature is referred to as body temperature. Piglets maintain their body temperature by reducing the exposure to the colder environment, for example, by huddling and by increasing their heat production by shivering [26-28]. Due to their lack of insulation, newborn piglets may be looked upon as one large thermal window, where the skin temperature is almost uniform throughout the body surface. A thermal window is a skin area, which is always well perfused by blood and as such is a "window" to the body temperature [29]. This in opposition to a non-thermal window, such as the ear flap or shoulder, where blood perfusion to the outer skin surface is controlled by thermoregulation. From here on, when referring to measured skin temperatures, they have been measured by IRT or IRTM, if not mentioned otherwise.

IRTME measures the surface temperature of pigs. The surface temperature of the skin (hairy or bare) is influenced by environmental ambient factors and the thermoregulatory response by the body that maintains a stable body temperature. Therefore, if an elevated skin temperature due to fever is to be detected correctly, it is necessary to quantify the effect of ambient temperature on skin temperature for non-febrile pigs. Ultimately, this should be included in a correction formula, which could be used for fever determination purposes. The few studies that have investigated this relationship are summarized in Table 1 . These studies vary in their approach regarding the area of skin, age, breed, experimental setting and use of different IRTME and methodology. This makes it impossible to combine the findings into one correction formula. However, studies have shown that skin areas with an increased fat layer (nonthermal window), which may be breed dependent, have a lower regression constant and higher coefficient [30]. This means that skin temperature is lower at low ambient temperatures due to the fat insulation, while increasing ambient temperature rapidly increases the skin temperature, due to the vasocontrolled thermoregulation, supplying more blood to the skin tissue. As expected, of the studies included in Table 1, the thermal windows exhibit higher regression constants and lower regression coefficients than the non-thermal windows, as they are less affected by the ambient room temperature.
Surface temperature in relation to core body temperature Knowing the skin temperature for non-febrile pigs under different ambient temperatures may not be enough for measuring elevated body temperature, which is the most important indicator of fever. A prerequisite for detecting elevated body temperature by measurement of skin temperature is a sufficient correlation between the two. Table 2 summarizes the studies that have investigated the correlation between skin surface temperatures measured using IRTME and body temperature. Usually, the body temperature remains relatively constant due to thermoregulation, but in certain situations, body temperature is regulated or altered: fever, hypothermia, digestion, parturition, and diurnal rhythm. Body temperature is usually determined by inserting a lubricated thermometer into the rectum, with the probe touching the mucus lining. Penetration depth depends on size of the pig, but in an adult sow, the probe should be inserted approx. $10 \mathrm{~cm}$ into the rectum. See Table 3 for normal rectal temperatures in resting pigs of different age at ambient temperatures in the thermoneutral zone.

\section{Correlation between skin and body temperature}

The limited amount of studies found in the literature that investigated the correlation between skin and body temperature include a range of ages from newborn piglets to old sows. Furthermore, the biological status of the investigated pigs was different, for example, with sows being investigated around the time of farrowing [31-33], slaughter pigs just killed with carbondioxide and exsanguinated in a stressful abattoir [7], and growing pigs being inoculated with Actinobacillus pleuropneumoniae [2]. This makes it difficult to compare the correlation between skin and body temperature even between the same skin areas. However, there are indications that the skin measurement sites for highest correlation to body temperature are the ears, eyes and udder. One study [32] found that the skin areas with the highest repeatability were the eyes and ears, even though the vulva skin area (when lying down) exhibited the highest correlation $(r=0.49)$ to body temperature. The standing position reduced the correlation substantially $(r=0.32)$, which is difficult to explain physiologically and may emanate from differences in methodology. In contrast, another study [14] did not find any correlation between vulva surface temperatures and body temperature, but a significant correlation between the vulva surface temperature and ambient temperatures was observed. This may be explained by the limited acclimatization period ( $30 \mathrm{~min}$.) and moisture in the vulva orifice, causing cooling by evaporation, since within the ROI, the minimum temperature was $20.6^{\circ} \mathrm{C}$ and the maximum was $35.6^{\circ} \mathrm{C}$.

The correlation between the ear skin and body temperature seems highly dependent on the exact location 
Table 1 Studies showing relationship between surface (measured by infrared devices) and ambient temperature in healthy pigs

\begin{tabular}{|c|c|c|c|c|c|c|c|c|c|c|}
\hline Source & $\mathrm{N}$ & Breed & $\begin{array}{l}\text { Approx. weight } \\
\text { (kg) }\end{array}$ & Surface area(s) & $\begin{array}{l}\text { Thermal Window } \\
\text { (X: yes) }\end{array}$ & $\begin{array}{l}T_{\text {ambient }} \\
{\left[{ }^{\circ} \mathrm{C}\right]}\end{array}$ & $\begin{array}{l}\text { Regression Constant, } \\
\mathrm{T}_{0}\left[{ }^{\circ} \mathrm{C}\right]\left({ }^{A}\right)\end{array}$ & $\begin{array}{l}\text { Regression } \\
\text { coefficient, } b\left({ }^{A}\right)\end{array}$ & $\begin{array}{l}\text { Correlation }(r) \text { and } \\
\text { goodness of fit }\left(R^{2}\right)\left({ }^{A}\right)\end{array}$ & Remarks \\
\hline $\begin{array}{l}\text { Henken } \\
\text { et al. [30] }\end{array}$ & 16 & $\begin{array}{l}\text { Norwegian, Finnish and } \\
\text { Dutch Landrace and } \\
\text { Great Yorkshire }\end{array}$ & 26 & Lumbal area & & $11-26$ & $22.5-25.9$ & $0.37-0.47$ & $r=0.83-0.91(* *)$ & $\left({ }^{B}\right)$ \\
\hline \multirow{2}{*}{$\begin{array}{l}\text { Wendt } \\
\text { et al. [34] }\end{array}$} & 89 & & $7-60$ & \multirow[t]{2}{*}{ Ear base } & \multirow[t]{2}{*}{$x$} & \multirow[t]{2}{*}{$12-30$} & 28.5 & \multirow[t]{2}{*}{0.263} & \multirow[t]{2}{*}{$r=-0.68(* * *)$} & \multirow[t]{3}{*}{$\left(c^{c}\right)$} \\
\hline & 147 & & $160-222$ & & & & 27.6 & & & \\
\hline $\begin{array}{l}\text { Loughmiller } \\
\text { et al. [2] }\end{array}$ & 4 & Crossbred & 30 & Loin & & $10-32$ & 24.8 & 0.40 & $\mathrm{R}^{2}=0.97$ (***) $^{*}$ & \\
\hline $\begin{array}{l}\text { Collin } \\
\text { et al. [35] }\end{array}$ & 8 & $\begin{array}{l}\text { [Large White } \times \\
\text { Landrace] } \times \text { Piétrain }\end{array}$ & $15-35$ & Interscapula region & & $23-33$ & 29.3 & 0.29 & $(* *)$ & $\left({ }^{(B)}\right)$ \\
\hline \multirow[t]{2}{*}{$\begin{array}{l}\text { Savary et al. } \\
\text { [36] }\end{array}$} & \multirow[t]{2}{*}{9} & & \multirow[t]{2}{*}{$50-70$} & $\begin{array}{l}\text { Ear base, abdomen } \\
\text { (caudal) and upper } \\
\text { medial side of legs }\end{array}$ & $x$ & $12-18$ & 30.6 & 0.36 & \multirow[t]{2}{*}{$(* * *)$} & \\
\hline & & & & $\begin{array}{l}\text { Carpus, tarsus, } \\
\text { shoulder, knee and } \\
\text { elbow }\end{array}$ & & & $25.2-27.1$ & 0.48 & & \\
\hline \multirow{2}{*}{$\begin{array}{l}\text { Costa } \\
\text { et al. [37] }\end{array}$} & \multirow[t]{2}{*}{12} & & 8 & \multirow{2}{*}{$\begin{array}{l}\text { Part of body with the } \\
\text { highest temperature }\end{array}$} & $x$ & $22-36$ & 30.8 & 0.20 & $R^{2}=0.44(* * *)$ & \\
\hline & & & 11 & & $x$ & $16-28$ & 33.7 & 0.20 & $R^{2}=0.57(* * *)$ & \\
\hline \multirow{3}{*}{$\begin{array}{l}\text { Malmkvist } \\
\text { et al. [31] }\end{array}$} & \multirow[t]{3}{*}{39} & \multirow{3}{*}{$\begin{array}{l}\text { Danish Landrace } \times \\
\text { Yorkshire }\end{array}$} & \multirow[t]{3}{*}{$>200$} & Eye & $x$ & $15-25$ & 32 & 0.2 & \multirow[t]{3}{*}{$(* * *)$} & \multirow[t]{3}{*}{$\left({ }^{B}\right)$} \\
\hline & & & & Snout & & & 28.7 & 0.3 & & \\
\hline & & & & Udder (caudal) & $x$ & & 32 & 0.2 & & \\
\hline
\end{tabular}

ssion coefficient $\left(=\mathrm{T}_{\text {skin }}\right.$ increase per $1^{\circ} \mathrm{C}$ increase in $\left.\mathrm{T}_{\text {ambient }}\right) . *{ }^{*}: P<0.01$ and $* *: P<0.001$.

${ }^{\mathrm{A}} \mathrm{T}_{\mathrm{skin}}=\mathrm{T}_{0}+\mathrm{b}^{*} \mathrm{~T} \mathrm{~T}_{\text {ambient }}$, where $\mathrm{T}_{0}=$ regression constant $\left[{ }^{\circ} \mathrm{C}\right], \mathrm{b}=$ regression coefficient $\left(=\mathrm{T}_{\text {skin }}\right.$ increase per $1^{\circ} \mathrm{C}$ increase in $\left.\mathrm{T}_{\text {ambient }}\right) .{ }^{* *}: P<0.01$ and ${ }^{* * *}: P<0.001$

${ }^{B}$ Estimations performed by author of this article.

${ }^{C}$ Based on thermocouple temperature measurements, not IR. 
Table 2 Studies showing relationship between surface (measured by infrared devices) and body temperature in pigs

\begin{tabular}{|c|c|c|c|c|c|c|c|c|}
\hline Source & $\mathrm{N}$ & Breed & Size/Age & Surface area(s) & $\begin{array}{l}\text { Thermal window } \\
\text { (X: yes) }\end{array}$ & $\mathrm{T}_{\text {ambient }}\left[{ }^{\circ} \mathrm{C}\right]$ & Correlation $(r)\left({ }^{A}\right)$ & Remarks \\
\hline \multirow[t]{10}{*}{ Zinn et al. [33] } & \multirow[t]{10}{*}{15} & \multirow[t]{10}{*}{ York $\times$ Landrace $(\mathrm{LR}) \times$ Duroc } & \multirow[t]{10}{*}{$225 \mathrm{~kg}$} & Eyeball & $x$ & \multirow[t]{10}{*}{ N/A } & $0.14 \rightarrow 0.51$ & \multirow{10}{*}{$\begin{array}{l}\text { Before } \rightarrow \text { after parturition. } \\
\text { Hairy sites were trimmed. }\end{array}$} \\
\hline & & & & Ear (outer side, $5 \mathrm{~cm}$ from base) & \multirow[t]{4}{*}{$x$} & & $0.12 \rightarrow 0.39$ & \\
\hline & & & & Tail head & & & $0.23 \rightarrow 0.29$ & \\
\hline & & & & Shoulder & & & $0.18 \rightarrow 0.47\left(^{*}\right)$ & \\
\hline & & & & Flank & & & $0.28 \rightarrow 0.42$ & \\
\hline & & & & Perineum & $x$ & & $0.21 \rightarrow 0.30$ & \\
\hline & & & & Vulva & $x$ & & $0.16 \rightarrow 0.23$ & \\
\hline & & & & Udder (cranial) & $x$ & & $0.06 \rightarrow 0.27$ & \\
\hline & & & & Udder (middle) & $x$ & & $0.12 \rightarrow 0.44$ & \\
\hline & & & & Udder (caudal) & $x$ & & $0.13 \rightarrow 0.39$ & \\
\hline Loughmiller et al. [2] & 24 & Crossbred & $30 \mathrm{~kg}$ & Loin & & $21 \pm 2$ & $0.52(* * *)$ & \\
\hline Warriss et al. [7] & 384 & & $\sim 91$ kg & Inner side of ear pinna & $x^{B}$ & 21 & $0.71(* * *)$ & $\left(c^{c}\right)$ \\
\hline \multirow[t]{6}{*}{ Traulsen et al. [32] } & \multirow[t]{6}{*}{42} & \multirow[t]{6}{*}{ Crossbred } & \multirow[t]{6}{*}{ 1st-6th parity } & Eyes & $x$ & \multirow[t]{6}{*}{$20.5-24.3$} & $0.33(*)$ & \\
\hline & & & & Udder & $x$ & & $0.41\left(^{*}\right)$ & \\
\hline & & & & Inner ear & $x$ & & $0.31\left(^{*}\right)$ & \\
\hline & & & & Ear base & $x$ & & $0.32\left(^{*}\right)$ & \\
\hline & & & & Vulva region (lying) & $x$ & & $0.49\left(^{*}\right)$ & \\
\hline & & & & Vulva region (standing) & $x$ & & $0.32(*)$ & \\
\hline \multirow[t]{3}{*}{ Magnani et al. [4] } & \multirow[t]{3}{*}{108} & & 10-17 days & Eye & $x$ & \multirow[t]{3}{*}{$22-30$} & 0.02 & \\
\hline & & & & Side, back and womb & $X^{B}$ & & $0.02-0.33$ & \\
\hline & & & & Axilla & $x$ & & 0.33 & \\
\hline \multirow[t]{3}{*}{ Chung et al. [38] } & \multirow[t]{3}{*}{10} & \multirow[t]{3}{*}{ Yorkshire × LR (Gnotobiotic) } & \multirow[t]{3}{*}{ Piglets } & Central abdomen & $x$ & \multirow[t]{3}{*}{$21 \pm 1$} & $0.58(* * *)$ & \\
\hline & & & & Central dorsum & & & $0.30(* * *)$ & \\
\hline & & & & Perianal region & $x$ & & $0.43(* * *)$ & \\
\hline \multirow[t]{3}{*}{ Malmkvist et al. [31] } & \multirow[t]{3}{*}{39} & \multirow[t]{3}{*}{ Danish LR $\times$ Yorkshire } & \multirow[t]{3}{*}{ 1st-3rd parity } & Snout & & \multirow[t]{3}{*}{$15-25$} & $0.21\left(^{* *}\right)$ & $\left({ }^{(}\right)$ \\
\hline & & & & Eye & $x$ & & $0.49\left(^{* * *}\right)$ & (D) \\
\hline & & & & Udder (caudal third) & $x$ & & $0.60(* * *)$ & (D) \\
\hline \multirow[t]{2}{*}{ Sykes et al. [14] } & \multirow[t]{2}{*}{32} & \multirow[t]{2}{*}{ Yorkshire $\times$ LR } & \multirow[t]{2}{*}{$\sim 85 \mathrm{~kg}$} & Vulva (estrus) & $x$ & \multirow[t]{2}{*}{$1.5-25.8$} & -0.099 to 0.011 & \\
\hline & & & & Vulva (diestrus) & $x$ & & -0.115 to -0.068 & \\
\hline
\end{tabular}


Table 2 Studies showing relationship between surface (measured by infrared devices) and body temperature in pigs (Continued)

\begin{tabular}{llllllll}
\hline Tabuaciri et al. [39] & 485 & Large White $(\mathrm{LW}) \times \mathrm{LR}, \mathrm{LW} \times$ Duroc & $<2 \mathrm{~kg}$ & Ear base & X & N/A & 0.85
\end{tabular}

Ear tip

Back (crown to rump)

0.75

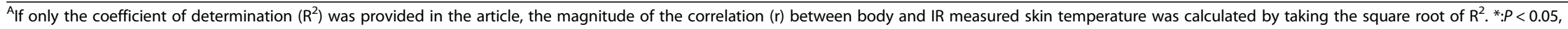

$* *: P<0.01, * * * P<0.001$.
${ }^{B}$ Indicates measurement sites that are both thermal windows and not thermal windows.

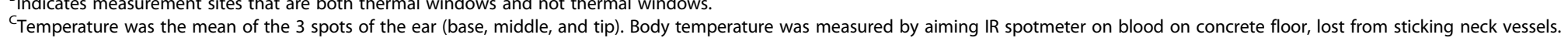

Temperature was the mean of the 3 spots of the ear 
Table 3 Normal rectal temperatures in resting pigs in the thermoneutral zone. Modified from [40]

\begin{tabular}{lc}
\hline Age & Normal rectal temperature, ${ }^{\circ} \mathbf{C}\left(\right.$ variation $\pm \mathbf{0 . \mathbf { 3 } ^ { \circ } \mathbf { C } )}$ \\
\hline Piglets & 39.5 \\
Slaughter pigs & 39.3 \\
Young sows, gilts & 38.8 \\
Multiparous sows & 38.3 \\
\hline
\end{tabular}

of which the skin temperature was measured. The ear flap is an important thermoregulatory area, while other areas such as the ear base and ear canal area may be considered thermal windows. This may explain the discrepant results reported $[4,7,32,33,39]$ and is nicely highlighted in the study by Tabuaciri et al. [39], who found a much higher correlation between the body and skin temperature of the ear base $(r=0.85)$ compared to the ear tip $(r=0.27)$. The study by Warriss et al. [7] differed from the other studies by the method used for measuring body temperature (see Table 2). Their reported high correlation $(r=0.71)$ could be due to the stunning damage to the pigs' brains, altering their vasocontrolled thermoregulation and the stressful situation in which the measurements took place (a commercial abattoir). Stress is known to have a significant effect on the surface temperatures of the ear and eyes [4] and the loin [2] in pigs. The initial vaso-constrictive response decrease the skin temperature, while after some time, this may subside, followed by an increase in skin temperature, releasing heat built up in the core from the initial vasoconstriction [2]. Similar results were found in rabbits [3] and cattle [41-43]. A low correlation coefficient $(r=0.02)$ between the eye and body temperature was observed in response to a stressor (a backtest) in pigs [4]. Other studies investigating the correlation between eye and body temperature reported higher correlation coefficients, which has also been reported in humans [44-46] and ponies [47]. Perhaps a pig study focusing specifically on the inner canthus, with adequate equipment (high spatial resolution and accuracy) and using the maximum pixel temperature would reveal higher correlation, as seen in humans [44-46]. The inner canthus of the eye was chosen as the best site for fever screening in humans $[48,49]$ due to the relatively easy access and its high correlation to body temperature. However, the high correlations reported were often based on tympanic temperature as the reference for body temperature and one study questions the suitability of the inner canthus to estimate body temperature [50], while another suggests the ear canal as a potentially better site [51]. Regardless, if the maximum temperature is to be detected in such relatively small areas or orifices as the inner canthus and the ear canal opening, the demand for a high spatial resolution is essential. Use of maximum or near maximum pixel temperatures for body temperature estimation in pigs is further supported by Traulsen et al. [32], who found that the maximum, average of the top-10\% or top-25\% IRT pixel temperatures in sows yielded higher body temperature correlation than average or minimum pixel temperatures for all the investigated surface areas (see Table 2).

A few studies performed a regression analysis of the skin - body temperature relationship in pigs (summarized in Table 4). Even at similar ambient temperatures, the studies reveal notably different regression constants and coefficients. This may be due to the limited variation in body temperature, even when observed animals were febrile. Furthermore, accuracy of the rectal thermometer measurements may be influenced by the experience of the operator and this may account for the variability between measurements. The only study that did not use rectal measurements for measuring the body temperature was also one of the studies with the highest regression coefficient [7]. They measured body temperature from blood lost from a sticking wound. However, with the large range of the measured body (blood) temperatures $\left(35.6-42.6^{\circ} \mathrm{C}\right)$, the results are questionable. Another explanation for the discrepant results in Table 4 (and Table 2) may be due to the skin body temperature relationship not being linear, at least for some skin areas. Malmkvist et al. [31] found an increased correlation coefficient $(r=0.32)$ for the snout if using a quadratic relationship vs. a linear $(r=0.21)$ and Traulsen et al. [32] found a significant quadratic relationship between the skin and body temperatures in all investigated skin areas other than the vulva and eyes (see Table 2).

\section{Detection of fever in pigs}

Fever, as determined by rectal temperature, has been shown to elevate the skin temperature significantly in pigs, although with an expected time delay [2]. However, the skin temperature does not increase equally over the entire pig surface. Traulsen et al. [32] observed average skin temperature increases in sows, ranging from $0.20^{\circ} \mathrm{C}$ for the vulva to $0.56^{\circ} \mathrm{C}$ for the inner ear and up to $0.99^{\circ} \mathrm{C}$ for the udder.

Johnson and Dunbar [52] reported a skin temperature increase 6 days post inoculation (classical swine fever) of 5.8, 12 and $10^{\circ} \mathrm{C}$ for the edge of ear, foot and entire body surface, respectively. They also observed the maximum temperature of the entire body surface was found inside the hind legs and on the dorsum of the pig. Similar results have been reported in pigs infected with the A. epizooticae virus (foot and mouth disease) with maximum foot skin temperature elevating by more than $10^{\circ} \mathrm{C}$ three days after infection [53].

Dewulf et al. [54] also investigated pigs with classical swine fever and deemed skin temperature measured using IRTM as insufficient for fever detection, since no reliable 
Table 4 Studies that investigated the linear regression between surface (measured by infrared devices) and body temperature

\begin{tabular}{|c|c|c|c|c|c|c|c|c|c|}
\hline \multirow[t]{2}{*}{ Source } & \multirow[t]{2}{*}{$\mathbf{N}$} & \multirow[t]{2}{*}{ Breed } & \multirow[t]{2}{*}{ Size/Age } & \multirow[t]{2}{*}{ Surface area(s) } & \multirow{2}{*}{$\begin{array}{l}\text { Thermal window } \\
\text { (X: yes) }\end{array}$} & \multirow[t]{2}{*}{$\mathrm{T}_{\text {ambient }}\left[{ }^{\circ} \mathrm{C}\right]$} & \multicolumn{2}{|c|}{ Regression $\left({ }^{A}\right)$} & \multirow[t]{2}{*}{ Remarks } \\
\hline & & & & & & & $\begin{array}{l}\text { Constant, } \\
\mathrm{T}_{0}\left[{ }^{\circ} \mathrm{C}\right]\end{array}$ & $\begin{array}{l}\text { Coefficient, } \\
\text { b }\end{array}$ & \\
\hline \multirow[t]{4}{*}{ Dewulf et al. [54] } & \multirow[t]{4}{*}{12} & \multirow[t]{4}{*}{ Belgian LR } & \multirow[t]{4}{*}{$12-15 \mathrm{~kg}$} & Ear & & \multirow[t]{4}{*}{$\sim 20$} & 38.80 & 0.015 & \\
\hline & & & & Flank & & & 37.82 & $0.044\left(^{* *}\right)$ & \\
\hline & & & & Legs (carpus and tarsus) & & & 38.24 & $0.032(* *)$ & \\
\hline & & & & Anus & $x$ & & 38.02 & $0.038(* *)$ & \\
\hline Warriss et al. [7] & 384 & & $\sim 91 \mathrm{~kg}$ & Inner side of ear pinna & $X^{B}$ & 21 & 4.93 & $1.12(* * *)$ & $r=0.71,\left(^{C}\right)$ \\
\hline \multirow[t]{4}{*}{ Chung et al. [38] } & \multirow[t]{4}{*}{10} & \multirow[t]{4}{*}{$\begin{array}{l}\text { Yorkshire } \times \text { LR } \\
\text { (Gnoto-biotic) }\end{array}$} & \multirow[t]{4}{*}{ Piglets } & $\begin{array}{l}\text { Eyelid, ear, parietal } \\
\text { and axilla }\end{array}$ & $X^{B}$ & \multirow[t]{4}{*}{$21 \pm 1$} & & & No significant relationship \\
\hline & & & & Central abdomen & $x$ & & 28.07 & $0.304\left(^{* * *}\right)$ & Adj. $R^{2}=0.34$ \\
\hline & & & & Central dorsum & & & 34.03 & $\left.0.1522^{(* *}\right)$ & Adj. $R^{2}=0.09$ \\
\hline & & & & Perianal region & $x$ & & 33.88 & $0.157\left(^{* * *}\right)$ & Adj. $R^{2}=0.19$ \\
\hline Kammersgaard et al. [55] & 91 & $\begin{array}{l}(\mathrm{LR} \times \text { Yorkshire }) \times \\
\text { Duroc }\end{array}$ & $1-48$ hours & $\begin{array}{l}\text { Entire piglet from dorsal view } \\
\text { and sagittal view }\end{array}$ & $x^{B}$ & 15,20 , and 25 & 14.72 & $0.63(* * *)$ & $\begin{array}{l}\text { Avg. of max. IR pixel temp. } \\
\text { from dorsal view and sagittal view }\end{array}$ \\
\hline
\end{tabular}

${ }^{A}$ Regression formula: $T_{\text {body }}=T_{0}+b^{*} T_{\text {skin }}$. Body temperature measurement site was the rectum if not otherwise mentioned. ${ }^{* *}: P<0.01$ and ${ }^{* * *}: P<0.001$.

${ }^{B}$ Indicates measurement sites that are both thermal windows and not thermal windows.

${ }^{\mathrm{C}}$ Temperature was the mean of the 3 spots of the ear (base, middle, and tip). Body temperature was measured by aiming IR spotmeter on blood on concrete floor, lost from sticking neck vessels. 
rectal temperature could be predicted, even though a significant correlation was observed (see Table 4). Wendt et al. [34] also investigated the diagnostic power by measuring ear base skin temperature, obtained by using regular thermocouple sensor put against skin. The sensitivity and specificity for sows were $79.0 \%, 69.3 \%$, respectively, with positive (healthy) and negative (febrile) predictive values of $78.5 \%$ and $70.0 \%$, respectively. Similarly for young pigs the numbers were $55.8 \%, 93.6 \%, 84.0 \%$ and $77.7 \%$, respectively. Schmidt et al. [56] were able to detect 6 and 7 febrile sows out of 10 , from eye and ear base temperature, respectively, where fever threshold values were based on $90 \%$ quantiles. Most of the diagnostic performance numbers presented in the mentioned studies are on the low side and may not be satisfactory in most settings. This may pertain to the delay between increase of skin and body temperature from febrile onset as observed in cattle [57].

One investigation used IRT for pen-level fever detection in pigs [58]. Instead of investigating the individual pigs for fever, the maximum temperature measured in pens with approx. 20 pigs was used for detection of pens with Actinobacillus pleuropneumoniae infection. Pens with mortality had significantly higher maximum pen temperature compared to three control pens (with no mortality) on the day that the mortality was observed, and the two days before. With each increase by $1^{\circ} \mathrm{C}$ in maximum pen temperature, the odds of a pen having mortality increased 3.6 times. The concept of using the group of pigs as its own control by comparing to a priori temperature measurements, was investigated further in another study [59], which found thermal response to a vaccination using a surveillance system.

\section{Detection of inflammation and lesions}

Sabec and Lazar [60] showed that boars with palpable symptoms of osteoarthrosis tarsi deformans had significant increased average skin temperature $\left(36.27^{\circ} \mathrm{C}\right)$ of the surrounding skin surface when compared to boars without palpable symptoms $\left(35.64^{\circ} \mathrm{C}\right)$. Savary et al. [36] showed that IRT enabled detection in $40 \%$ of leg joints with proven acute inflammation, but only $9.5 \%$ of leg joints with chronic inflammation. With their diagnosis criteria, IRT indicated approx. $10 \%$ of leg joints in healthy pigs to be inflamed. They observed large temperature differences $\left(>1^{\circ} \mathrm{C}\right)$ between symmetrical regions in more than one fourth of the leg joint measurements in healthy pigs, questioning reliability of this method for detecting inflammation based on asymmetry alone. The measured asymmetries in healthy pigs of $>1^{\circ} \mathrm{C}$ are high compared to the max of $0.5^{\circ} \mathrm{C}$ found in healthy humans $[61,62]$. This discrepancy could be explained by the housing facilities in which pigs rest. One could speculate that hard floors would cause elevated temperatures on the surface areas bearing the weight of the pig, causing major changes in the subdermal tissue, as is seen in sows with decubital pressure ulcers [63].

Active dynamic thermography (ADT) is a method by which IRT recordings following an external heat or cold exposure may reveal differences in the underlying tissue of the surface in question due to different recooling or reheating patterns. Thermal properties of pig skin have been shown to change when burned $[64,65]$. In these studies, pig skin was used for modeling human skin and they showed that ADT performed just as well as the histopathological method (reference), in evaluating skin burn depth, whereas the clinical method (using traditional observational criteria) and static IRT performed worse. The ADT and hisopathological methods performed equally, exhibiting $100 \%$ accuracy, sensitivity, and specificity. For the clinical method, these 3 numbers were $60.9 \%, 50 \%$, and $100 \%$, respectively, while for the static IRT method, the numbers were $91.3 \%, 94.4 \%$, and $80.0 \%$, respectively. ADT has also been found to be superior compared with static IRT when characterizing wound types and assessing pressure ulcers [66].

\section{Improving infrared measurements and their applications Fever diagnosis}

Obviously, we cannot claim that IRT should be the new gold standard for detecting fever in pigs from the diagnostic test results reported in the literature.

There is a great demand for a comprehensive study using calibrated, accurate IRTME investigating pigs from different age groups (with known fat layer), at different skin areas, and at a varying range of ambient temperatures. Findings from this could result in correction formulae (linear or quadratic), which could be used in a number of different settings, where variation in ambient temperature, age, and skin location could be accounted for. Ultimately, this would then be used as a rough baseline value; from which discrepancies could be attributed, e.g. fever. Furthermore, including ADT in future diagnostic tests may reveal that this method is not only suited for detecting localized skin damage or inflammation $[64,65]$, but also for elevated systemic temperatures.

Adopting techniques as proposed by Ng and Kee [67] could further improve diagnosis. Ng and Kee [67] used a combination of parabolic regression, learning algorithms and receiver operating characteristics (ROC) analysis instead of the conventional method consisting of linear regression and ROC analysis. In doing so, they increased the accuracy of diagnoses in fever screenings of humans. Accuracy rate for the same measurements was increased from $93 \%$ to $96 \%$, while sensitivity and specificity changed from $85.4 \%$ and $95 \%$ to $95 \%$ and $85.6 \%$, respectively.

\section{Standardization protocols}

The diagnostic toolbox additions as mentioned above may be insufficient for improving fever detection from IRT 
measurements. If the skin measurements themselves are inaccurate, fever diagnosis will inevitably be inaccurate. However, todays advanced IR cameras provide fairly accurate temperature measurements with good spatial and thermal resolution. Furthermore, diagnoses based on skin measurements using IRT could be improved considerably by creation of standardization protocols as have been made for fever screening in humans $[48,49,68]$. Operators of IR cameras should be trained properly, knowing the limitations of the equipment [69]. This could reduce the variability in temperature measurements due to operator errors, e.g. wrong choice of skin emissivity or incorrect measurement of reflection temperature [70]. In addition to this, introducing the Digital Imaging and Communication in Medicine (DICOM) standard in the field of IRT in general as suggested by some scientists $[71,72]$ will be a valuable addition. If used correctly, this will enable researchers and scientists to compare IRT measurements performed with different devices by different operators knowing that factors like distance, reflections, angles, emissivity, poorly calibrated devices, etc. have been taken into consideration for best possible measurement results. Obviously, thermal properties between animal species and breeds are different due to several factors, such as body temperature set points, thermoneutral zone differences, thermal windows, and hair density. These factors should be considered when comparing any temperature measurements.

\section{Conclusions}

Further research on use of IRT for pig health screening is still needed before it can be used as a reliable diagnostic tool. Studies performed to date are inconclusive due to much variance in results. Most of which are likely to arise from inaccurate measurements and methodology differences. IRT shows great potential in some health applications where it may become superior to other methods. However, ground research incorporating metrological approaches for accurate measurements is necessary to make IRT a reliable standardized method for detection of changes in body surface temperatures due to fever, inflammation, stress, pain or other conditions.

Thorough investigations of surface temperature distributions of healthy pigs of different age groups, breeds and in different environments is the first step towards improving detection of unhealthy pigs. Furthermore, skin temperature progression at different stages in the course of fever for various diseases should be made. This could enable detection of sick animals prior to evidence of clinical symptoms.

\section{Competing interests}

The authors declare that they have no competing interests.

\section{Authors' contributions}

DDS reviewed the literature and drafted the major parts of manuscript. LJP made substantial contributions to the drafting of the manuscript. Both authors read and approved the final manuscript.

\section{Acknowledgments}

The authors greatly appreciate the input from Katrine Kop Fogsgaard, Mette S. Herskin and Trine Sund Kammersgaard from Department of Animal Science at Aarhus University in shaping this review. The work was supported by The Danish National Advanced Technology Foundation and Danish Centre for Animal Welfare.

Received: 24 March 2014 Accepted: 12 January 2015

Published online: 03 February 2015

\section{References}

1. Grant R. Emotional hypothermia in rabbits. Am J Physiol. 1950;160:285-90.

2. Loughmiller JA, Spire MF, Dritz SS, Fenwick BW, Hosni MH, Hogge SB. Relationship between mean body surface temperature measured by use of infrared thermography and ambient temperature in clinically normal pigs and pigs inoculated with Actinobacillus pleuropneumoniae. Am J Vet Res. 2001;62:676-81.

3. Ludwig N, Gargano M, Luzi E, Carenzi C, Verga M. Technical note: applicability of infrared thermography as a non invasive measurement of stress in rabbit. World Rabbit Sci. 2007;15:199-205.

4. Magnani D, Gatto M, Cafazzo S, Stelletta C, Morgante M, Costa LN. Difference of surface body temperature in piglets due to the backtest and environmental condition. In: Conference Proceedings of International Society for Animal Hygiene: 20116 July; Vienna. 2011. p. 1029-32.

5. Stewart M, Webster JR, Stafford KJ, Schaefer AL, Verkerk GA. Technical note: effects of an epinephrine infusion on eye temperature and heart rate variability in bull calves. J Dairy Sci. 2010;93:5252-7.

6. Vianna DML, Carrive P. Changes in cutaneous and body temperature during and after conditioned fear to context in the rat. Eur J Neurosci. 2005;21:2505-12

7. Warriss PD, Pope SJ, Brown SN, Wilkins LJ, Knowles TG. Estimating the body temperature of groups of pigs by thermal imaging. Vet Rec. 2006;158:331-4.

8. Costa L, Stelletta C, Cannizzo C, Gianesella M, Lo Fiego D, Morgante M. The use of thermography on the slaughter-line for the assessment of pork and raw ham quality. Ital J Anim Sci. 2007;6:704-6.

9. Dikeman M, Spire M, Hunt M, Lowak S. National Pork Board Report NPB \#02-025. 2003. p. 1-9. http://old.pork.org/filelibrary/researchdocuments/02025-dikeman.10-17-03.pdf.

10. Gariepy C, Amiot J, Nadai S. Ante-mortem detection of DSE and DFD by infrared thermography of pigs before stunning. Meat Sci. 1989;25:37-41.

11. Lawrence TE, Spire MF, Dikeman ME, Hunt MC, Hogge SB, James BW. Utilizing infrared thermography to predict pork quality, Swine Day Kansas State University. 2001. p. 131-4

12. Schaefer $A L$, Jones SDM, Murray AC, Sather AP, Tong AKW. Infrared thermography of pigs with known genotypes for stress susceptibility in relation to pork quality. Can J Anim Sci. 1989;69:491-5.

13. Simoes VJG. Variations in the vulvar temperature of sows as determined by infrared thermography and its relation to ovulation. PhD Thesis. Universidade Tecnica de Lisboa. Faculdade de Medicina Veterinaria; 2012

14. Sykes D, Couvillion J, Cromiak A, Bowers S, Schenck E, Crenshaw M, et al. The use of digital infrared thermal imaging to detect estrus in gilts. Theriogenology. 2012;78:147-52.

15. Scolari SC, Clark SG, Knox RV, Tamassia MA. Vulvar skin temperature changes significantly during estrus in swine as determined by digital infrared thermography. J Swine Health Prod. 2011;19:151-5.

16. Lopez J, Goodband RD, Allee GL, Jesse GW, Nelssen JL, Tokach MD, et al. The effect of diets formulated on an ideal protein basis on growthperformance, carcass characteristics, and thermal balance of finishing gilts housed in a hot, diurnal environment. J Anim Sci. 1994;72:367-79.

17. Loughmiller JA, Spire MF, Tokach MD, Dritz SS, Nelssen JL, Goodband RD, et al. An evaluation of differences in mean body surface temperature with infrared thermography in growing pigs fed different dietary energy intake and concentration. J Appl Anim Res. 2005;28:73-80.

18. Wilcox S. Thermographic evaluation of metabolic changes in swine. Thermology Int. 2007;17:133-6. 
19. Montagna W, Yun JS. The skin of the domestic pig. J Invest Dermatol. 1964:43:11-21.

20. Costa LN. Short-term stress: the case of transport and slaughter. Ital J Anim Sci. 2009:8:241-52

21. Knizkova I, Kunc P, Gurdil G, Pnar Y, Selvi K. Applications of infrared thermography in animal production. J Fac Agric OMU. 2007;22:329-36

22. Mccafferty DJ. The value of infrared thermography for research on mammals: previous applications and future directions. Mamm Rev. 2007:37:207-23.

23. Rohlinger $P$, Gunther M, Danz J, Lyhs L, Zimmerhackel M. Zur anwendung der infrarottechnik in der veterinärmedizin. Arch Exp Veterinarmed. 1979;33:851-6.

24. Stewart M, Webster JR, Schaefer AL, Cook NJ, Scott SL. Infrared thermography as a non-invasive tool to study animal welfare. Anim Welf 2005;14:319-25.

25. Manners MJ, McCrea MR. Changes in the chemical composition of sowreared piglets during the 1st month of life. Brit J Nutr. 1963;17:495-513.

26. Berthon D, Herpin P, Le Dividich J. Shivering thermogenesis in the neonatal pig. J Therm Biol. 1994;19:413-8.

27. Mount LE. The climatic physiology of the pig. London: Edward Arnold; 1968.

28. Mount LE. Adaptation to thermal environment: man and his productive animals. London: Edward Arnold; 1979.

29. Nielsen KS. Animal physiology - adaptation and environment. New York: Cambridge University Press; 1997.

30. Henken AM, Brandsma HA, Vanderhel W, Verstegen MWA. Heat-balance characteristics of limit-fed growing pigs of several breeds kept in groups at and below thermal neutrality. J Anim Sci. 1991;69:2434-42.

31. Malmkvist J, Pedersen LJ, Kammersgaard TS, Jorgensen E. Influence of thermal environment on sows around farrowing and during the lactation period. J Anim Sci. 2012;90:3186-99.

32. Traulsen I, Naunin K, Muller K, Krieter J. Untersuchungen zum einsatz der infrarotthermographie zur messung der körpertemperatur bei sauen. Zuchtungskunde. 2010;82:437-46

33. Zinn KR, Zinn GM, Jesse GW, Mayes HF, Ellersieck MR. Correlation of noninvasive surface-temperature measurement with rectal temperature in swine. Am J Vet Res. 1985;46:1372-4.

34. Wendt M, Eickhoff K, Koch R. Die messung der hauttemperatur als methode zur erkennung fieberhaft erkrankter schweine. Deut Tierarztl Woch. 1997;104:29-33.

35. Collin A, Vaz MJ, Le Dividich J. Effects of high temperature on body temperature and hormonal adjustments in piglets. Reprod Nutr Dev. 2002:42:45-53.

36. Savary P, Hauser R, Ossent P, Jungbluth T, Gygax L, Wechsler B. Eignung der thermographie zur erfassung von entzündungen an den gliedmassen von mastschweinen. Deut Tierarztl Woch. 2008;115:324-9.

37. Costa LN, Redaelli V, Magnani D, Cafazzo S, Amadori M, Razzauoli E, et al. Preliminary study on the relationship between skin temperature of piglets measured by infrared thermography and environmental temperature in a vehicle in transit. In: LXIV Annual Meeting of the Italian Society for Veterinary Sciences: 8-10 September 2010; Asti, Italy. 2010. p. 193-7.

38. Chung TH, Jung WS, Nam EH, Kim JH, Park SH, Hwang CY. Comparison of rectal and infrared thermometry for obtaining body temperature of gnotobiotic piglets in conventional portable germ free facility. Asian Australas J Anim Sci. 2010;23:1364-8.

39. Tabuaciri P, Bunter KL, Graser HU. Thermal imaging as a potential tool for identifying piglets at risk. In: AGBU Pig Genetics Workshop. Armidale, Australia: Animal Genetics and Breeding Unit, University of New England; 2012

40. Larsen LP, Baekbo P. Sundhed og sygdom hos svin. Aarhus, Denmark: Landbrugsforlaget; 2005.

41. Stewart M, Webster JR, Verkerk GA, Schaefer AL, Colyn JJ, Stafford KJ. Non-invasive measurement of stress in dairy cows using infrared thermography. Physiol Behav. 2007;92:520-5.

42. Stewart M, Schaefer AL, Haley DB, Colyn J, Cook NJ, Stafford KJ, et al Infrared thermography as a non-invasive method for detecting fear-related responses of cattle to handling procedures. Anim Welf. 2008;17:387-93.

43. Stewart M, Stafford KJ, Dowling SK, Schaefer AL, Webster JR. Eye temperature and heart rate variability of calves disbudded with or without local anaesthetic. Physiol Behav. 2008;93:789-97.

44. Hughes WT, Patterson GG, Thornton D, Williams BJ, Lott L, Dodge R. Detection of fever with infrared thermometry - a feasibility study. J Infect Dis. 1985;152:301-6.

45. Pascoe DD, Fisher G. Comparison of measuring sites for the assessment of body temperature. Thermology Int. 2009;19:35-42.
46. Ring EFJ, Jung A, Zuber J, Rutowski P, Kalicki B, Bajwa U. Detecting fever in Polish children by infrared thermography. In: Proceedings of the 9th International Conference on Quantitative Infrared Thermography: 2-5 July 2008; Krakow. 2008. p. 125-8.

47. Johnson SR, Rao S, Hussey SB, Morley PS, Traub-Dargatz JL. Thermographic eye temperature as an index to body temperature in ponies. J Equine Vet Sci. 2011;31:63-6.

48. International Electrotechnical Commission (IEC). Medical electrical equipment-part 2-59 standard: Particular requirements for the basic safety and essential performance of screening thermographs for human febrile temperature screening, IEC 80601-2-59. Geneva: International Electrotechnical Commission; 2008.

49. International Organization for Standardization (ISO). Medical electrical equipment - deployment, implementation and operational guidelines for identifying febrile humans using a screening thermograph, ISO/TR 13154. Geneva: International Organization for Standardization; 2009.

50. Teunissen LPJ, Daanen HAM. Infrared thermal imaging of the inner canthus of the eye as an estimator of body core temperature. J Med Eng Tech. 2011;35:134-8.

51. Cardoso A. Screening fever, a new approach. Thermology Int. 2012;22:105.

52. Johnson SR, Dunbar MR. Infrared thermography: its use and application for detecting infectious diseases in wildlife and domestic animals. In: InfraMation 2010 Proceedings: 2010; Las Vegas. 2010. p. 102-1-8.

53. Bashiruddin JB, Mann J, Finch R, Zhang Z, Paton D. Preliminary study of the use of thermal imaging to assess surface temperatures during foot-andmouth disease virus infection in cattle, sheep and pigs. Report of the 2006 Session of the Research Group of the Standing Technical Committee of the European Commission for the Control of Foot-and-Mouth Disease (Appendix 46), 2006 17-20 October; Paphos, Cyprus. Rome: Food and Agriculture Organization; 2006. p. 304-8.

54. Dewulf J, Koenen F, Laevens $H$, de Kruif A. Infraroodthermometrie is ongeschikt voor de detectie van koorts bij varkens. Vlaams Diergen Tijds. 2003;72:373-9.

55. Kammersgaard TS, Malmkvist J, Pedersen LJ. Infrared thermography - a noninvasive tool to evaluate thermal status of neonatal pigs based on surface temperature. Animal. 2013;7:2026-34.

56. Schmidt M, Lahrmann K-H, Ammon C, Berg W, Schön P, Hoffmann G. Assessment of body temperature in sows by two infrared thermography methods at various body surface locations. J Swine Health Prod. 2013;21:203-9.

57. Schaefer AL, Cook NJ. Heat generation and the role of infrared thermography in pathological conditions. In: Luzi F, Mitchell M, Costa LN, Redaelli V, editors. Current status and advances in livestock animals and in veterinary medicine. Brescia, Italy: Fondazione Iniziative Zooprofilattiche e Zootecniche; 2013. p. 69-78.

58. Friendship R, Poljak Z, Mclntosh K. Use of infrared thermography for early detection of disease causing sudden death in a swine finishing barn. 28th Annual Centralia Swine Research Update, 28 January 2009; Ontario. 2009. p. $1-27-8$.

59. Cook NJ, Schaefer AL. Infrared thermography and disease surveillance. In: Luzi F, Mitchell M, Costa LN, Redaelli V, editors. Current Status and Advances in Livestock Animals and in Veterinary Medicine. Brescia, Italy: Fondazione Iniziative Zooprofilattiche e Zootecniche; 2013. p. 79-92.

60. Sabec D, Lazar P. Preliminary results of noncontact temperature measuring using an infrared thermometer on the tarsus of swine with osteoarthrosis tarsi deformans. Deut Tierarztl Woch. 1990;97:43-4.

61. Uematsu S. Symmetry of skin temperature comparing one side of the body to the other. Thermology. 1985;1:4-7.

62. Niu HH, Lui PW, Hu JS, Ting CK, Yin YC, Lo YL, et al. Thermal symmetry of skin temperature: normative data of normal subjects in Taiwan. Chin Med Taipei. 2001;64:459-68.

63. Herskin M, Bonde M, Jorgensen $\mathrm{E}$, Jensen K. Decubital shoulder ulcers in sows: a review of classification, pain and welfare consequences. Animal. 2011;5:757-66

64. Renkielska A, Nowakowski A, Kaczmarek M, Ruminski J. Burn depths evaluation based on active dynamic IR thermal imaging - a preliminary study. Burns. 2006;32:867-75.

65. Ruminski J, Kaczmarek M, Renkielska A, Nowakowski A. Thermal parametric imaging in the evaluation of skin burn depth. IEEE Trans Biomed Eng. 2007;54:303-12.

66. Hansen $G L$, Sparrow EM, Kaleita AL, laizzo PA. Using infrared imaging to assess the severity of pressure ulcers. Wounds. 1998;10:43-53. 
67. Ng EYK, Kee EC. Fever mass screening tool for infectious diseases outbreak: integrated artificial intelligence with bio-statistical approach in thermogram analysis. Diakides NA, Bronzino JD, editors. Medical Infrared Imaging 1st ed. Boca Raton: CRC Press; 2007. p. 16.1-16.19.

68. Ring E, Ammer K. Infrared thermal imaging in medicine. Physiol Meas. 2012;33:R33-46.

69. Plassmann P, Ring EFJ, Jones CD. Quality assurance of thermal imaging systems in medicine. Thermology Int. 2006;16:10-5.

70. Soerensen DD, Clausen S, Mercer JB, Pedersen LJ. Determining the emissivity of pig skin for accurate infrared thermography. Comput Electron Agr. 2014;109:52-8.

71. Ruminski J. Representation of thermal infrared imaging data in the DICOM using XML configuration files. 29th Annual International Conference of the IEEE - Engineering in Medicine and Biololgy Society: 22-26 August 2007; Lyon. 2007. p. 258-62.

72. Schaefer G, Huguet J, Zhu S, Plassmann P, Ring F. Adopting the DICOM standard for medical infrared images. 28th Annual International Conference of the IEEE - Engineering in Medicine and Biololgy Society: 30 August - 3 September 2006; New York. 2006. p. 236-9.

\section{Submit your next manuscript to BioMed Central and take full advantage of:}

- Convenient online submission

- Thorough peer review

- No space constraints or color figure charges

- Immediate publication on acceptance

- Inclusion in PubMed, CAS, Scopus and Google Scholar

- Research which is freely available for redistribution 